\title{
Entrepreneurial Intentions of Business Students: A Matter of Masculinity and Femininity
}

\author{
Davy Vercruysse ${ }^{1,}$, , Stephanie Birkner ${ }^{2}$ \\ ${ }^{1}$ Department of Accountancy, Corporate Finance \& Fiscality, Faculty of Economics and Business Administration, Ghent University, Ghent, \\ Belgium \\ ${ }^{2}$ Department of Economics and Law, Faculty II, Oldenburg University, Oldenburg, Germany
}

Email address:

davy.vercruysse@ugent.be (D. Vercruysse), stephanie.birkner@zukunft-unternehmen.io (S. Birkner)

${ }^{*}$ Corresponding author

\section{To cite this article:}

Davy Vercruysse, Stephanie Birkner. Entrepreneurial Intentions of Business Students: A Matter of Masculinity and Femininity. European Business \& Management. Vol. 7, No. 3, 2021, pp. 72-84. doi: 10.11648/j.ebm.20210703.13

Received: May 27, 2021; Accepted: June 10, 2021; Published: June 21, 2021

\begin{abstract}
The purpose of this paper is to investigate the entrepreneurial intention of business students, with an emphasis on their masculine and feminine characteristics, instead of the usual classification male / female. While recent studies have increased the understanding of the implications of being a man or woman (sex differences) on entrepreneurial intention, papers which examine whether masculinity and/or femininity (gender differences) impact entrepreneurial intention are rare. The following paper offers insights into the latter research gap by quantitatively investigating the genderedness of intentions of business students, which is of particular importance for fostering entrepreneurship. The Theory of Planned Behavior is used as underlying framework, with entrepreneurial intention as dependent variable and its three antecedents ('attitude towards behavior', 'subjective norms', and 'perceived behavior control'). A survey is administered and filled out by 501 Belgian business students of different universities. Masculinity and femininity are measured by the Bem Sex Role Inventory Model. The results are analyzed by structural equation modeling. Students with high masculinity have significant higher entrepreneurial intentions than students with low masculinity. There is a significant association between masculinity and entrepreneurial intentions through the mediating role of attitude towards behavior and subjective norms. Furthermore femininity has a positive impact on entrepreneurial intentions with subjective norms as mediator. This study contributes to the debate which personality traits influence entrepreneurial intention and further deepens the discussion how educators could approach different types of students in order to stimulate their interest in entrepreneurship. Previously conflicting results about the impact of sex on entrepreneurial intention can perhaps be solved if studies are in the future enriched with socially constructed gender variables.
\end{abstract}

Keywords: Entrepreneurial Intention, Sex, Gender, Masculinity, Femininity, Structural Equation Modeling, Mediation

\section{Introduction}

The call for more entrepreneurs has found its way from a side note in economic research to a strategic topic of key importance in political mission statements of e.g. the United Nations [1] or the European Commission [2]. Entrepreneurship is said to e.g. positively affect job creation and foster regional growth [3] as well as internationalization [4].

Previous research has focused primarily on male entrepreneurs [5-7], which is surprising since women-owned businesses significantly contribute to wealth creation in all economies [8]. So the call for more entrepreneurs has become a greater focus, particularly in research agendas examining how to foster women's entrepreneurship [e.g. 9]. Here, studies have primarily concentrated on the differences between men and women [10-12] and as such have placed an empirical emphasis on sex analysis (male/female).

The importance of integrating gender analysis (masculinity / femininity) into entrepreneurship research has evoked continued steps forward [13]. Via gender analysis, the socially constructed aspects of masculinity and femininity have become more prominent when analyzing the genderedness of entrepreneurial contexts [14-17], identities [18] or activities [19]. While this development of a new research agenda is promising, and a lot has in fact happened in politics, academia 
and education in the last two decades, there is still much to be done in both the scientific and practical realms [20]: after mapping the status quo regarding women's entrepreneurship so far, they state that more profound research regarding gender and entrepreneurship in Europe is necessary.

This paper ultimately aims to give the insight whether sex and / or gender affect entrepreneurial intentions of students, and whether the three antecedents (attitude towards behavior, subjective norms and perceived behavioral control) mediate this relationship.

This study wants to give an answer to the following question: does a higher or lower score in entrepreneurial intention depend on the fact whether a person:

1. is male or female?

2. has high or low masculinity?

3. has high or low femininity?

This paper is conceptually based on the entrepreneurial intention survey designs related to the Theory of Planned Behavior [21] in combination with gender analysis approaches working with the Bem Sex Role Inventory Model [22]. Based on the insights of a literature review on the status quo of (1) women's entrepreneurship research and (2) entrepreneurial intention, a conceptual model is developed linking these two discourses through a combined sex and gender analysis perspective in a survey on 501 business management students. While former research about gender and entrepreneurial intention has mostly been conceptually performed or via qualitative research designs, this study provides new insights into the genderedness of EI using a quantitative survey. The direct and indirect effects are observed via structural equation modeling, delivering new empirical contributions.

\section{Literature Review}

\subsection{The Gap in Entrepreneurship Research}

As brought forth in the introduction, women's entrepreneurship has been for a long time an understudied topic [e.g. 23]. The low historical attention to this topic was for the first time criticized during the 1980's by Birley [24] among others, claiming that men and women have different cultural, natural and historical backgrounds. However, at that time entrepreneurship was almost only studied via male samples and conclusions were taken in a more general way. In that period, only a few studies targeted specifically female samples [25-27]. In the 1990's studies concluded that women were (still) subject to patriarchal pressure, which influenced the self-employment of women [28]. Mirchandani [29] identified similarities and differences between female and male entrepreneurs, giving reasoning why there were less female entrepreneurs. Ahl [9] brings forth that research on women entrepreneurs suffered from a number of shortcomings and consequently asks for new directions in research on women's entrepreneurship.

Coming back to this plea, new research streams came up resulting in several publications during the last fifteen years as single articles as well as special issues in renowned journals like Entrepreneurship Theory and Practice [5, 6, 30], International Journal of Entrepreneurial Behavior \& Research [31] and Small Business Economics [16] among others. Since 2009, the International Journal of Gender and Entrepreneurship is distinctively publishing articles about women's entrepreneurship as an own field of research. During the last decade, more attention is drawn towards women's entrepreneurship in combination with field of interest ranging from business financing [32], networking [33] and also in relation towards entrepreneurship education [34] only to mention a few. Further perspectives came up, offering a new gender-aware framework of women entrepreneurship [14], building theory development [15], dealing with the discourse of entrepreneurial masculinities [35] and raising more gaps in women's entrepreneurship research [36].

In context of this paper, Ahl [9] illustrated with a biographical analysis that entrepreneurial identities in research are portrayed as masculine: more studies in an entrepreneurship context should also explore the impact of masculinity and femininity to provide more understanding of the social construction of gendered entrepreneurial identities. [37] claim entrepreneurship is related to the performance of masculine practices while [7] state that images of female entrepreneurship are stereotyped in a pejorative way. In academic research and also in the media, entrepreneurs are mostly represented as male stereotypes and women are under-represented [35]. In particular, for this paper, the prominent discourse on entrepreneurial intention has been for quite some time biased towards the study of men as brought forward in the following section.

\subsection{The Study of Entrepreneurial Intention}

It can be assumed that entrepreneurial intentions predict entrepreneurship and explain why someone considers and starts a new venture [38]. Since entrepreneurship research indicates that entrepreneurial behavior succeeds entrepreneurial intention [39], EI is a very strong predictor of planned behavior [40], e.g. regarding starting a business or not. This makes entrepreneurship a type of planned behavior for which these intention models are ideally suited [38].

Since the Theory of Planned Behavior (TPB) of [21] is seen as very consistent and robust [39] and there has been extensive research on it [41-43], the TPB will be used as the main model to conceptually frame this paper. The TPB model establishes three antecedents or independent predictors of entrepreneurial intention:

1. Attitude Towards Behavior (ATB) is the attitude a person has towards, in this case, entrepreneurial behavior. The higher the ATB score, the stronger it will positively influence the EI of that person.

2. Subjective Norm (SN) measures the social pressure someone feels from others in respect to the desired behavior. The more encouragement an individual gets from others, the stronger the EI of that person will become.

3. Perceived Behavioral Control (PBC) or the belief someone has in order to execute his or her behavior: the 
perception a person has about how easy it is to start up or not. The easier a person thinks it is to start as an entrepreneur, the more likely it will be that he or she becomes self-employed.

For this article, EI and its three antecedents will be surveyed, since the direct impact of sex, masculinity and femininity on entrepreneurial intentions, as well as the indirect effects of these three predictors via the mediation effects of its three antecedents will be measured. So far, only the mediation effects of the three antecedents have been discussed for sex [44] but not for masculinity nor femininity.

\subsection{Entrepreneurial Intention and Sex Analysis}

Many articles emphasize the difference in entrepreneurial intentions via the Theory of Planned Behavior in the context of sex analysis between men and women. In former literature, male students have a significantly higher intention towards entrepreneurship than female students $[45,46]$. In other words, female students expressed lower entrepreneurial intentions than their male counterparts [47]. Consequently, we hypothesize:

H1a: Being male has a positive direct impact on EI.

Previous studies show that women (including female students) have a less positive attitude towards entrepreneurship and a lower desire to start businesses of their own [48]. Other recent studies that affirm this lower level of attitudes towards entrepreneurship are [49-51]. Furthermore, other scholars showed in their study that there is a mediation effect for attitudes towards behavior between sex and EI [44]. Therefore, we hypothesize:

$\mathrm{H} 1 \mathrm{~b}$ : Being male has a positive indirect impact on EI via ATB.

Another stream of research claims that women do not easily find support within their family $[10,52]$ and that they are more willing to take on the responsibility of raising their children [53]. Women adapt their behavior due to the responsibility of the norms and values in life, and this more than their male counterparts do. In line with [44], we hypothesize:

H1c: Being male has a positive indirect impact on EI via SN.

Last, the reason why women show less intention to start up can be due to various reasons: women tend to be more risk averse [54]. Another reason is they do not get easily find support from financial institutions [55] by which they have less control over their entrepreneurial situation. Based on these mentioned articles, we expect:

H1d: Being male has a positive indirect impact on EI via PBC.

However, as discussed in the introduction of this paper, sex analysis is only one side of the coin of entrepreneurship research. It uncovers the chances and challenges for fostering women's entrepreneurship. The genderedness of entrepreneurship and the genderedness of entrepreneurial intention in particular needs to be considered as well.

\subsection{Entrepreneurial Intention and Gender Analysis}

With the growing awareness of the historical inattention to women entrepreneurship research from a more nuanced perspective $[56,57]$, there is plea to address sex and gender from their own distinct or, even more pronounced, a combined analysis perspective. Research traditions have shifted when it comes to the focus within women's entrepreneurship [58], even though the distinction of sex and gender analysis still has not appeared in many articles. Some conceptual papers focus on gender studies and gendered discourses [35, 59], although empirical papers mostly survey sex, while surveys on EI and the effect of gender (i.e. socially constructed masculinity / femininity) remain rare. However, more and more researchers are aware that women's entrepreneurship should not (only) be limited to sex analysis. Recent research states that gender role orientation (masculinity and femininity) is seen as a better indicator of entrepreneurial intentions and behavior [60]. Starting a firm is not only influenced by being a man or a woman, but more attention should be drawn to the impact of the socially constructed gender and gender role orientation, which find their base in Social Feminist Theory [61]: men and women have different cultural backgrounds and different ways of thinking. Sex is seen as the physiological difference between men and women, while gender refers to culturally specific patterns of behavior, including entrepreneurial behavior [62].

The masculinity and femininity of individuals can be measured based on the Sex Role Inventory by Bem [22]. This scale remains the most commonly used validated scale regarding gender role orientation [63]. Individuals can have high or low masculine and feminine scores, without a high score of masculinity excluding a high score of femininity.

Entrepreneurs are perceived as having characteristics similar to those of masculine gender-role stereotypes: men and women have higher entrepreneurial intentions when they possess masculine characteristics and attributes [64]. Reference [55] also indicates that a "good" entrepreneur is predominantly described using masculine attributes. In line with this, other scholars concluded that entrepreneurs and business people tend to be more hostile and predatory, which is seen as masculine [64]. Indeed, masculine individuals show higher scores of entrepreneurial behavior than others [60]. Their conclusion finds strength by other papers because people with high masculinity display higher self-esteem and possess higher career self-efficacy or perceived behavioral control [65]. In another study, more than half of the individuals classify themselves according to a gender role different from their biological sex, while EI is better explained by this gender role with masculine attributes than via sex [66]. All in all, masculine characteristics are for this reason positively associated with entrepreneurship and entrepreneurial intention [67].

The following hypotheses are proposed in line with the emphasized implications of research on EI and masculinity:

$\mathrm{H} 2 \mathrm{a}$ : Masculinity has a positive direct impact on EI.

$\mathrm{H} 2 \mathrm{~b}$ : Masculinity has a positive indirect impact on EI via ATB.

$\mathrm{H} 2 \mathrm{c}$ : Masculinity has a positive indirect impact on EI via SN.

$\mathrm{H} 2 \mathrm{~d}$ : Masculinity has a positive indirect impact on EI via PBC.

While literature provides insights that masculine norms, which are of benefit in the start-up world, are linked to higher EI, successful entrepreneurs tend to have also some feminine attributes like helping others, understanding, being emotional, etc. [68]. Contrary to that, recent studies give raise to the 
assumption that the dominance of the socially constructed femininity can have a more negative effect to become an entrepreneur. Feminine individuals are socially constructed as the "others" in entrepreneurial (ecosystem) discourses: being inadequate and/or extraordinary without taking into account the social and structural conditions that shape their entrepreneurial intention and action [69]. Indeed, empirical evidence is found that the preferences of entrepreneurial pitches is moderated by masculinity in respect of physical attractiveness while femininity is negatively associated to EI [70]. A dissonance of discourses on socially constructed attributes of womanhood and entrepreneurship [18] respectively a "lack of fit" of the socially constructed impact framing of feminine stereotypes and entrepreneurship [71] dominates the start-up world. Reference [66] states that feminine characteristics can be associated negatively with becoming an entrepreneur, since these people are more sensitive to the needs of others, which is incompatible with becoming an entrepreneur. Accordingly, researchers assume that feminine orientated persons show a lower attitude (ATB) towards entrepreneurial behavior [67, 72]. By the social pressure $(\mathrm{SN})$ they feel, they have a lower desire of entrepreneurial behavior and such a lower belief that they have to execute entrepreneurial behavior (PBC) which ends up in a lower EI [60]. Therefore, in line with these findings the following hypotheses are proposed:

H3a: Femininity has a negative direct impact on EI (compared to non-femininity).

$\mathrm{H} 3 \mathrm{~b}$ : Femininity has a negative indirect impact on EI via ATB.

$\mathrm{H} 3 \mathrm{c}$ : Femininity has a negative indirect impact on EI via SN.

$\mathrm{H} 3 \mathrm{~d}$ : Femininity has a negative indirect impact on EI via PBC.

An overview of the research agenda proposed so far is shown in Figure 1, which visualizes the conceptual model with the formulated hypotheses and relationship between the variables. Curved lines are expressing the direct effects, straight lines are showing the indirect effects.

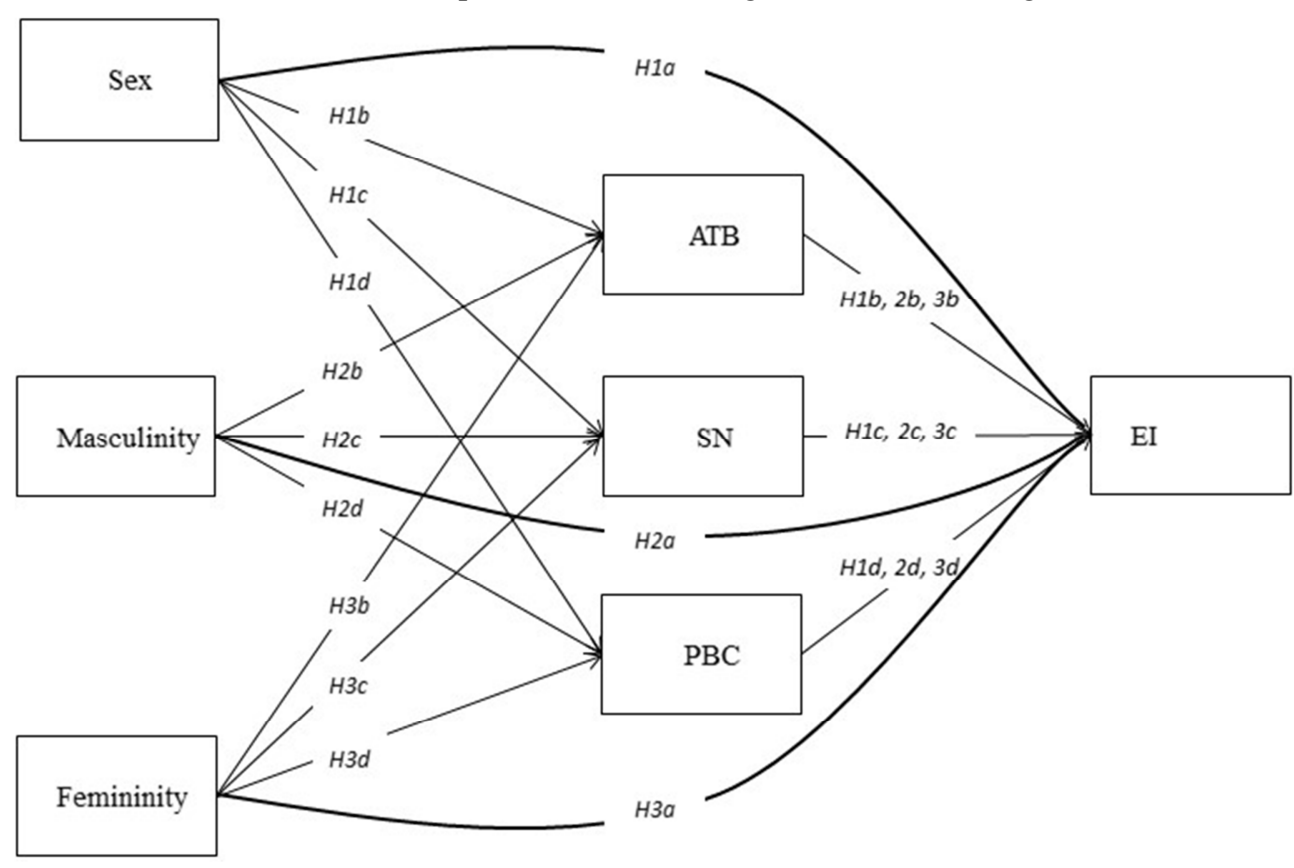

Figure 1. The conceptual model.

\section{Methodology}

\subsection{Sample Description}

The hypotheses were tested using a quantitative questionnaire survey. The samples for this study were two large cohorts of undergraduate students in business management and business administration at two different universities in Flanders, Belgium. All of the students were local students and native Dutch speakers. The survey was administered during official class time. One of the researchers explained that the purpose of the survey was research, stressing that this was a voluntary activity. Anonymity was guaranteed, and no course credit was obtained for participation. The gross sample of the surveys consists of 525 students who filled out the questionnaire. After a check of full completion and a proof of data cleaning, 501 questionnaires remained as the net sample for the data analysis.

\subsection{Contextual Background of Flanders}

Since the survey is taken in Flanders, the northern part of Belgium, some contextual background about this region is provided because entrepreneurial aspects can differ per region [73]. In the past days, Flanders was seen as an entrepreneurial region, but in the early start of the millennium, Flanders (and also Belgium) was found less entrepreneurial compared to other European countries [74]. More recently, the Global Entrepreneurship Monitor Report for Belgium and Flanders concludes there is still a lot of work to do in order to stimulate entrepreneurship: there exists a lack of entrepreneurial culture in Flanders since fear of failure is a structural barrier among those who see good opportunities to start a business [75]. 
Although there are gender gaps in the benchmark countries (e.g. Germany, France, Netherlands,...), the score for women believing in their own capabilities to start up is the lowest in Flanders [75]. Because of these reasons, and specific emphasizing on the gender gap, we wanted to perform this study in order to see what the situation nowadays is in Flanders among students who are studying business management and by doing so consider to become an entrepreneur in future.

\subsection{Measurement Scales}

Measurement scales were taken from previously validated research. The items were translated from English into Dutch to avoid any language issues by the survey participants. To control for translation bias, the items were also translated back into English. A pilot test was performed with 20 students to test the comprehensibility and for any inconsistence in the questionnaire, where no adaptations were needed. Of the effective sample, the Kaiser-Meyer-Olkin test for sample adequacy was high (0.869) and Berlett's sphericity test was highly significant $(\mathrm{p}=0.00)$, so the data are suitable for factor analysis. Besides factor analysis, the reliability of every variable was tested. A description of every variable is given.

Entrepreneurial intention as the dependent variable was measured by the mean score of eight items on a 7-point Likert scale (1 totally disagree; 7 totally agree). Six of the eight items are similar to [76]. Two extra items were added based on the research of reference [77]. Cronbach's alpha was 0.959 , showing a reliable measure, which is comparable to former research [76]. Attitude towards behavior (ATB) was measured by five items according to [76]. To assess the reliability, Cronbach's alpha of 0.866 was calculated and in the factor analysis the five independent variables loaded on the appropriate construct. Subjective norms (SN) was measured using the scale developed by [78]. The Cronbach's alpha score of SN was 0.903 , and all factors loaded on the same factor in the factor analysis. Perceived behavior control (PBC) was measured, based on the scale of [79] and validated by the work of [80]. With 0.624 , the Cronbach's alpha of the initial six items was low. By deleting items 3, 5 and 6, the final PBC achieved a reliability score of 0.739 , which is comparable to previous research [81].

Masculinity and femininity were measured via the Bem Sex Role Inventory [22], using the shortened version with ten items of femininity and ten items of masculinity, validated in later research [82]. Concerning masculinity, only item 8 was deleted due to the factor analysis, giving a Cronbach Alpha of 0.891 and here as well all items loaded on the same factor. For femininity, excluding item 10 gave a CA-score of 0.865 . The remaining 9 items all loaded on the same factor in the factor analysis (see Table 1).

Sex (male/female) and the origin of university were measured by a dummy. Based on previous research, data was controlled for age $[83,84]$ and parental entrepreneurship [85, 86].

Table 1. Reliability and factor analysis of the continuous variables.

\begin{tabular}{|c|c|c|c|}
\hline Variables & Cronbach & Factor & Source \\
\hline Attitude towards behavior (1 totally disagree; 7 totally agree) & 0.866 & & \multirow{6}{*}{$\begin{array}{l}\text { Based on } \\
\text { Liñán and } \\
\text { Chen }[76]\end{array}$} \\
\hline 1. Being an entrepreneur implies more advantages than disadvantages to me. & $\mathrm{X}$ & 0.662 & \\
\hline 2. A career as an entrepreneur is not attractive for me. & $\mathrm{X}$ & 0.716 & \\
\hline 3. If I had the opportunity and resources, I'd like to start a firm. & $\mathrm{X}$ & 0.724 & \\
\hline 4. Being an entrepreneur would entail no satisfaction for me. & $\mathrm{X}$ & 0.676 & \\
\hline 5. Among various options, I would rather be an entrepreneur. & $\mathrm{X}$ & 0.699 & \\
\hline Subjective norms (1 totally disagree; 7 totally agree) & 0.903 & & \multirow{4}{*}{$\begin{array}{l}\text { Based on } \\
\text { Fayolle, } \\
\text { Gailly } \\
{[78]}\end{array}$} \\
\hline 1. I value the opinion of my family * I believe my closest family members think I should become an entrepreneur. & $\mathrm{X}$ & 0.817 & \\
\hline 2. I value the opinion of my best friends * I believe my best friends think I should become an entrepreneur. & $\mathrm{X}$ & 0.850 & \\
\hline $\begin{array}{l}\text { 3. I value the opinion of people who are important to me } * \text { I believe the people who are important to me think I } \\
\text { should become an entrepreneur. }\end{array}$ & $\mathrm{X}$ & 0.826 & \\
\hline Perceived behavior control (1 totally disagree; 7 totally agree) & 0.739 & & \multirow{6}{*}{$\begin{array}{l}\text { Based on } \\
\text { Souitaris, } \\
\text { Zerbinati } \\
{[80] \text { and }} \\
\text { Kolvereid } \\
{[79]}\end{array}$} \\
\hline 1. For me, being self-employed would be very difficult. & $\mathrm{X}$ & 0.757 & \\
\hline 2. If I wanted to, I could easily pursue a career in self-employment. & $\mathrm{X}$ & 0.713 & \\
\hline 3. Being self-employed, I would have complete control over the situation. & & & \\
\hline $\begin{array}{l}\text { 4. The number of events outside my control which could prevent me from being self-employed are very few. } \\
\text { 5. If I became self-employed, the chances of success would be very low. }\end{array}$ & $\mathrm{X}$ & 0.644 & \\
\hline 6. If I pursue a career in self-employment, the chances of failure would be very low. & & & \\
\hline Masculinity (1 totally disagree; 7 totally agree) & 0.891 & & \multirow{9}{*}{$\begin{array}{l}\text { Based on } \\
\text { Bem [22] } \\
\text { and } \\
\text { Campbell, } \\
\text { Gillaspy } \\
\text { Jr [82] }\end{array}$} \\
\hline 1. Willing to take a stand & $\mathrm{X}$ & 0.716 & \\
\hline 2. Defends own beliefs & $\mathrm{X}$ & 0.777 & \\
\hline 3. Independent & $\mathrm{X}$ & 0.623 & \\
\hline 4. Has leadership abilities & $\mathrm{X}$ & 0.774 & \\
\hline 5. Strong personality & $\mathrm{X}$ & 0.833 & \\
\hline 6. Forceful & $\mathrm{X}$ & 0.794 & \\
\hline 7. Dominant & $\mathrm{X}$ & 0.698 & \\
\hline 8. Aggressive & & & \\
\hline 9. Assertive & $\mathrm{X}$ & 0.656 & \\
\hline 10. Willing to take risks & $\mathrm{X}$ & 0.573 & \\
\hline Femininity (1 totally disagree; 7 totally agree) & 0.865 & & Based on \\
\hline 1. Affectionate & & & Bem [22] \\
\hline 2. Warm & $\mathrm{X}$ & 0.720 & and \\
\hline
\end{tabular}




\begin{tabular}{|c|c|c|c|}
\hline Variables & Cronbach & Factor & Source \\
\hline 3. Compassionate & $\mathrm{X}$ & 0.678 & Campbell, \\
\hline 4. Gentle & $\mathrm{X}$ & 0.712 & Gillaspy \\
\hline 5. Tender & $\mathrm{X}$ & 0.708 & $\operatorname{Jr}[82]$ \\
\hline 6. Sympathetic & $\mathrm{X}$ & 0.729 & \\
\hline 7. Sensitive to needs of others & $\mathrm{X}$ & 0.590 & \\
\hline 8. Sooth hurt feelings & $\mathrm{X}$ & 0.679 & \\
\hline 9. Understanding & $\mathrm{X}$ & 0.718 & \\
\hline 10. Loves children & $\mathrm{X}$ & 0.696 & \\
\hline
\end{tabular}

\section{Results}

\subsection{Descriptive Statistics}

The descriptive statistics are shown in Table 2.

Table 2. Descriptive statistics.

\begin{tabular}{|c|c|c|c|c|c|}
\hline Panel A & $\mathbf{N}$ & Minimum & Maximum & Mean & S. D. \\
\hline EI & 501 & 1.00 & 7.00 & 3.99 & 1.52 \\
\hline ATB & 501 & 1.40 & 7.00 & 5.05 & 1.16 \\
\hline SN & 501 & 1.00 & 6.67 & 4.08 & 1.11 \\
\hline PBC & 501 & 1.00 & 7.00 & 4.10 & 1.12 \\
\hline Masculinity & 501 & 1.60 & 7.00 & 4.76 & 0.91 \\
\hline Femininity & 501 & 2.50 & 6.80 & 5.00 & 0.75 \\
\hline Age & 501 & 20.00 & 28.00 & 21.50 & 1.56 \\
\hline \multicolumn{2}{|l|}{ Panel B } & $\mathbf{N}$ & & \multicolumn{2}{|c|}{ Percentage } \\
\hline \multicolumn{6}{|l|}{ Sex } \\
\hline \multicolumn{2}{|l|}{ Male } & 252 & & \multicolumn{2}{|l|}{$50.3 \%$} \\
\hline \multicolumn{2}{|l|}{ Female } & 149 & & \multicolumn{2}{|l|}{$49.7 \%$} \\
\hline \multicolumn{6}{|c|}{ Parental Entrepreneurship } \\
\hline \multicolumn{2}{|l|}{ Yes } & \multicolumn{2}{|l|}{253} & \multicolumn{2}{|l|}{$50.4 \%$} \\
\hline No & & 248 & & \multicolumn{2}{|l|}{$49.6 \%$} \\
\hline \multicolumn{6}{|c|}{ University 1 or 2} \\
\hline \multicolumn{2}{|l|}{ University 1} & 264 & & \multicolumn{2}{|l|}{$52.7 \%$} \\
\hline \multicolumn{2}{|l|}{ University 2} & 237 & & \multicolumn{2}{|l|}{$47.3 \%$} \\
\hline
\end{tabular}

Panel A describes the continuous variables, while panel B describes the categorical variables. The overall mean for entrepreneurial intention is 3.99 , which is high or similar compared to other studies in a similar setting. In [81] EI scored 3.3, while in [76] the score in the pretest was 4.01 and 3.77 in the posttest. The mean score of attitude towards behavior is 5.05 , which is quite high compared to other research work: in [87], ATB scored 4.49. The scores of subjective norms and perceived behavioral control are also in line with the other work [46].

In general, students scored higher on femininity (mean=5.00) than on masculinity (mean=4.76). Scores are comparable to former research $[82,88]$. Age varies between 20 and 28, with a mean of 21.5 years. Concerning the categorical control variables, there is an almost equal division between male (252) and female (249) students, and also between students who have parents who are entrepreneurs (253), and those who do not have entrepreneurial parents (248). Of the 501 participants, 264 students come from University 1 while 237 students are from University 2.

The correlation matrix in Table 3 reveals that EI is significantly and positively correlated with ATB ( $\mathrm{r}=0.823$, $\mathrm{p}=0.00), \mathrm{SN}(\mathrm{r}=0.558, \mathrm{p}=0.00), \operatorname{PBC}(\mathrm{r}=0.310, \mathrm{p}=0.00)$, masculinity $(r=0.386, p=0.00)$ and $\operatorname{sex}(r=0.225, p=0.00)$.

Table 3. Correlation matrix.

\begin{tabular}{|c|c|c|c|c|c|c|c|c|c|}
\hline & 1 & 2 & 3 & 4 & 5 & 6 & 7 & 8 & 9 \\
\hline 1. EI & 1 & & & & & & & & \\
\hline 2. ATB & $.823^{* *} 0.000$ & 1 & & & & & & & \\
\hline 3. $\mathrm{SN}$ & $.558^{* *} 0.000$ & $.465^{* *} 0.000$ & 1 & & & & & & \\
\hline 4. $\mathrm{PBC}$ & $.310^{* *} 0.000$ & $.369^{* *} 0.000$ & 0.0590 .190 & 1 & & & & & \\
\hline 5. Masculinity & $.386^{* *} 0.000$ & $.376^{* *} 0.000$ & $.243^{* *} 0.000$ & $.280^{* *} 0.000$ & 1 & & & & \\
\hline 6. Femininity & .0160 .719 & -.0190 .670 & $.152^{* *} 0.001$ & -.0730 .100 & -.0870 .052 & 1 & & & \\
\hline 7. Age & $.089^{*} 0.001$ & .0840 .059 & .0120 .794 & $.147^{*} 0.001$ & $\begin{array}{l}0.129^{* *} \\
0.004\end{array}$ & $\begin{array}{l}-.030^{* *} \\
0.497\end{array}$ & 1 & & \\
\hline 8. Sex & $.225^{* *} 0.001$ & $.191^{* *} 0.000$ & $\begin{array}{l}-.072^{* *} \\
0.106\end{array}$ & $.093^{*} 0.037$ & $.153^{* *} 0.001$ & $\begin{array}{l}-.293^{* *} \\
0.000\end{array}$ & $.089^{*} 0.047$ & 1 & \\
\hline 9. $\mathrm{PE}$ & $.228^{* *} 0.000$ & $.265^{* *} 0.000$ & $.220^{* *} 0.000$ & $.198^{* *} 0.000$ & .0780 .080 & .0180 .692 & .0030 .944 & -.0580 .195 & 1 \\
\hline
\end{tabular}




\begin{tabular}{|c|c|c|c|c|c|c|c|c|c|}
\hline & 1 & 2 & 3 & 4 & 5 & 6 & 7 & 8 & 9 \\
\hline 10. U1-U2 & -.0040 .927 & -.0150 .746 & -.0280 .537 & $\begin{array}{l}-.157^{* *} \\
0.000\end{array}$ & $-.090^{*} 0.044$ & -.0050 .912 & $\begin{array}{l}-.643^{* *} \\
0.000\end{array}$ & .0500 .267 & -.0590 .191 \\
\hline
\end{tabular}

A significantly high correlation $(r=0.465, \mathrm{p}=0.00)$ between the independent variables ATB and SN. Variance Inflation Factors (VIF) are calculated to detect whether there appears to be a problem of multicollinearity. Since the threshold for the VIF is 2.50 [89], no multicollinearity is detected since this threshold is never crossed.

Before performing the structural equation modeling procedure, the data is tested for outliers and non-normality. Based on [90] no outliers were identified in the data (outliers are based on the inter-quartile range rule multiplier of 3 ). A Shapiro-Wilk test was performed to check for normality of the main variables. Comparable to the work of [76], who applied the same questionnaire in order to create an instrument to measure entrepreneurial intention, normality was not supported.

For cases with non-normality, [91] recommend to use the bootstrap technique to test if this non-normality undermines the statistical power, especially in cases to test for mediation. Following the advice of [92], 5000 replications for the bootstrap were used in a regression analysis to test the robustness of the dataset: the result is a good model fit with $\mathrm{F}=255,72$ and $\mathrm{p}=0,000$.

\subsection{Hypotheses Testing}

Hypotheses H1a-d are testing whether sex (being male or female) has an impact on entrepreneurial intention, hypotheses 2a-d test what the impact of masculinity is on entrepreneurial intention and hypotheses 3a-d test what the impact of femininity is on EI. Data was analyzed with SPSS 25 and the structural equation modeling (SEM) is performed with StataMP 15. Adding covariance errors between ATB, SN and $\mathrm{PBC}$, the model fit is perfect (RMSEA $=0.00$, chi-square $=0.64, \mathrm{NFI}=1.00$, standardized $\mathrm{RMR}=0.005$ ).

The analysis via SEM (Figure 2 and Tables $4 \& 5$ ) makes it possible to detect the direct and indirect impact of effects in the model. Solid lines show the significant relations, dotted lines the insignificant ones for sex, masculinity and femininity.

Direct effects are shown in table 5. Hypothesis H1a predicted that "sex (being male) has a positive direct impact on EI (compared to being female)," and this is supported, leading to an acceptation of H1a $(\mathrm{p}=0.000)$, with a T-value of 4.56. Hypothesis H2a "masculinity has a positive direct impact on EI (compared to non-masculinity)," is supported, with a T-value of $2.23(\mathrm{p}=0.026)$, which means that hypothesis $\mathrm{H} 2 \mathrm{a}$ can be accepted as well. Hypothesis H3a "femininity has a negative direct impact on EI (compared to non-femininity)," is not supported $(\mathrm{p}=0.182)$. In fact there is no significant change, which means that hypothesis $\mathrm{H} 3 \mathrm{a}$ is rejected.

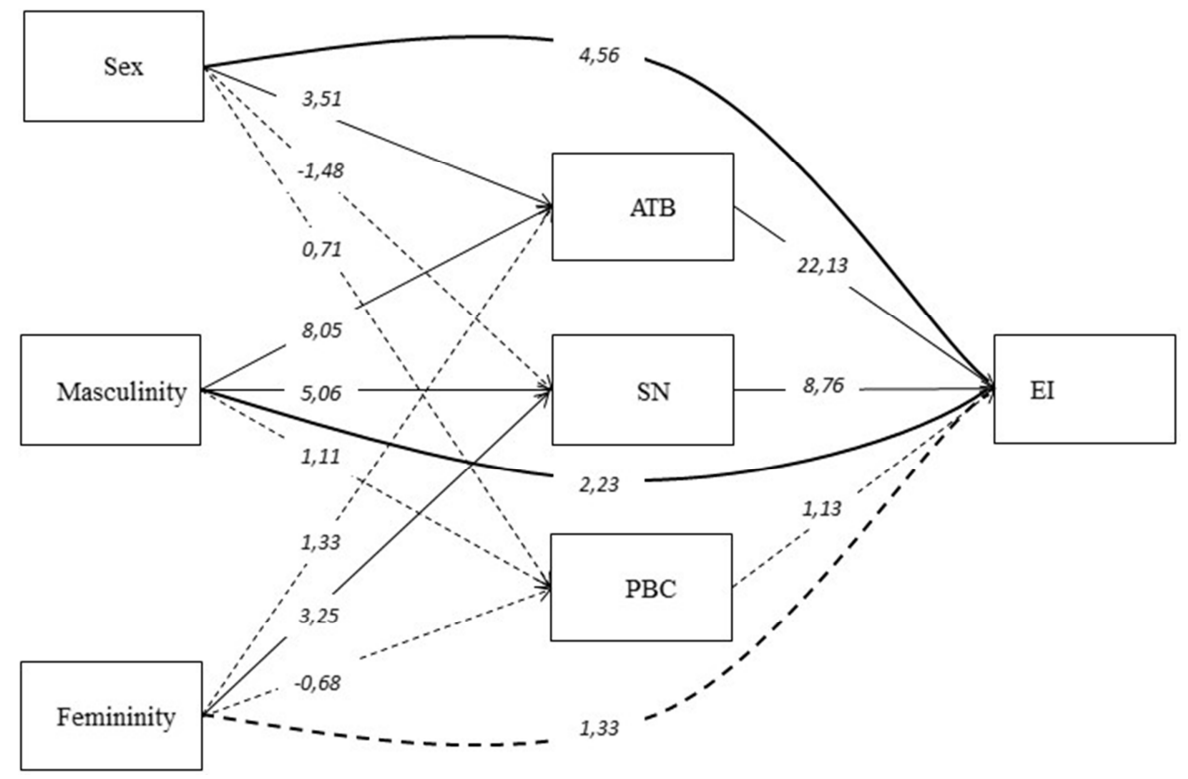

Figure 2. The conceptual model.

Table 4. Overview of the direct effects via SEM with EI as independent variable.

\begin{tabular}{|c|c|c|c|c|c|}
\hline Predictor & Coef & Std Err & $\mathbf{Z}$ & $\mathbf{p}>|\mathbf{z}|$ & Hypothesis \\
\hline ATB & 0.867 & 0.039 & 22.13 & $0.000^{*}$ & $1 b, 2 b, 3 b$ \\
\hline $\mathrm{SN}$ & 0.327 & 0.037 & 8.76 & $0.000 *$ & $1 \mathrm{c}, 2 \mathrm{c}, 3 \mathrm{c}$ \\
\hline PBC & 0.039 & 0.034 & 1.13 & 0.258 & $1 \mathrm{~d}, 2 \mathrm{~d}, 3 \mathrm{~d}$ \\
\hline Sex & 0.347 & 0.076 & 4.56 & $0.000^{*}$ & $1 \mathrm{a}$ \\
\hline Masculinity & 0.096 & 0.341 & 2.23 & $0.026^{*}$ & $2 a$ \\
\hline Femininity & 0.066 & 0.043 & 1.33 & 0.182 & $3 a$ \\
\hline
\end{tabular}


With hypotheses $1 b-d, 2 b-d$ and $3 b-d$, we test the indirect effects. In this diagram, there are two significant effects visible from masculinity to the antecedents since to the scores of the T-values are higher than 1.96. Furthermore, this is also the case for sex to ATB and for femininity to SN. To test however whether this indirect effect from one predictor (sex, masculinity or femininity) to EI via a mediator (ATB, SN or PBC) is significant, additional calculations are needed via the Sobel test $[93,94]$. These additional analyses were performed in Stata MP 15 and are shown in Table 5, allowing the remaining hypotheses to be tested.

Hypothesis 1b "Sex (being male) has a positive indirect impact on EI via ATB" can be accepted since there was a positive effect of sex connected to ATB with a coefficient of 0.307 ( $p=0.000$ ). Hypothesis 1c "Sex (being male) has a positive indirect impact on EI via SN" can be rejected since $\mathrm{p}=0.138$. In the same way, hypothesis $1 \mathrm{~d}$ "Sex (being male) has a positive indirect impact on EI via PBC" needs to be rejected since there was no significant effect of sex on EI through $\mathrm{PBC}$ with $\mathrm{p}=0.480$.

Hypothesis 2b "Masculinity has a positive indirect impact on EI via ATB" can be accepted since $\mathrm{p}=0.000$ with a coefficient of 0.396. Hypothesis 2c "Masculinity has a positive indirect impact on EI via SN" can be accepted as well, with a coefficient of $0.108 \quad(p=0.000)$. Hypothesis $2 d$ "Masculinity has a positive indirect impact on EI via PBC" has to be rejected because there was no significant effect of masculinity on EI through $\mathrm{PBC}$ with $\mathrm{p}=0.265$.

Hypothesis $3 b$ "Femininity has a negative indirect impact on EI via ATB" is rejected since $\mathrm{p}=0.184$. Hypothesis $3 \mathrm{c}$ "Femininity has a negative indirect impact on EI via SN" needs to be rejected as well: in fact femininity has a positive impact on EI with $\mathrm{SN}$ as mediator $(\mathrm{p}=0.001)$ with a coefficient of $0.075(\mathrm{p}=0.000)$. Hypothesis $3 \mathrm{~d}$ "Femininity has a negative indirect impact on EI via PBC" has to be rejected because there was no significant effect of masculinity on EI through $\mathrm{PBC}$ with $\mathrm{p}=0.265$.

Table 5. Indirect effects of the predictors via the Sobel test.

\begin{tabular}{|c|c|c|c|c|c|c|}
\hline Mediator & Predictor & Coef & Std Err & $\mathbf{Z}$ & $\mathbf{p}>|\mathbf{z}|$ & Нур \\
\hline ATB & Sex & 0.307 & 0.088 & 3.51 & $0.000 *$ & $1 \mathrm{~b}$ \\
\hline $\mathrm{SN}$ & Sex & -0.049 & 0.033 & -1.48 & 0.138 & $1 \mathrm{c}$ \\
\hline PBC & Sex & 0.036 & 0.005 & 0.71 & 0.480 & $1 d$ \\
\hline ATB & Masculinity & 0.396 & 0.049 & 8.05 & $0.000 *$ & $2 b$ \\
\hline SN & Masculinity & 0.108 & 0.021 & 5.06 & $0.000 *$ & $2 \mathrm{c}$ \\
\hline PBC & Masculinity & 0.013 & 0.012 & 1.11 & 0.265 & $2 d$ \\
\hline $\mathrm{SN}$ & Femininity & 0.075 & 0.023 & 3.25 & $0.001 *$ & $3 c$ \\
\hline PBC & Femininity & -0.002 & 0.003 & -0.68 & 0.497 & $3 d$ \\
\hline
\end{tabular}

\subsection{Additional Insights}

Along with the hypotheses testing, additional analysis of both sexes separately provided more detailed insights. Based on the work of Lenney [95], a median split is performed, classifying the students with more or less masculinity than the median, and more or less femininity than the median to study the differences of EI between masculine males and females versus non-masculine males and females.
When only male students are observed in an ANCOVA with EI as a dependent variable, and masculinity is set as a dummy using a median split (median masculinity is 4,80 ) in relation to the control variables, masculinity is an important factor (Table 6). Masculine males have significantly more EI than non-masculine males: the estimated marginal means of EI of masculine males was 4.69 , for non-masculine males the estimated marginal means of EI was 3.92 .

Table 6. ANCOVA with EI as a dependent variable with masculinity and control variables for males and females.

\begin{tabular}{|c|c|c|c|c|}
\hline & \multicolumn{2}{|c|}{ Males } & \multicolumn{2}{|c|}{ Females } \\
\hline & $\mathbf{F}$ & Sig & $\mathbf{F}$ & Sig \\
\hline Age & 0.30 & 0.584 & 2.33 & 0.128 \\
\hline Parental Entrepreneurship & 20.21 & $0.000 *$ & 12.33 & $0.001 *$ \\
\hline Femininity & 0.02 & 0.885 & 7.32 & $0.007^{*}$ \\
\hline University 1 or 2 & 0.73 & 0.392 & 0.87 & 0.352 \\
\hline Masculinity $(1 / 0)$ & 17.70 & $0.000 *$ & 16.64 & $0.000 *$ \\
\hline
\end{tabular}

There is a significant difference for female students as well. When only females are observed in an ANCOVA with EI as a dependent variable, and masculinity is set as a dummy using the median split in relation to the control variables, masculinity is here as well an important factor. Masculine females have significantly more EI than non-masculine females: the estimated marginal means of EI of masculine females is 4.05 , for non-masculine females the estimated marginal means of EI is 3.33 . However, the femininity score of male or female students did not matter in terms of EI. 


\section{Conclusion}

\subsection{Discussion of Hypotheses and Findings}

This paper aimed to investigate whether EI and its antecedents are affected by sex (male/female) and/or gender (masculinity/femininity). The present study finds a positive relationship between sex and entrepreneurial intentions via a positive direct impact (H1a) and also indirect via attitudes towards entrepreneurship (H1b). This finding is in line with preceding studies that have discussed the fact that male students have more entrepreneurial intentions or attitude towards entrepreneurship than female students $[45,51]$.

More important, this study presents that masculinity has a positive direct impact on entrepreneurial intentions (H2a) and, indirect via attitudes (H2b) and subjective norms (H2c). Furthermore, this study shows a positive indirect impact from femininity on entrepreneurial intentions via subjective norms (H3b). Quantitative surveys exploring the effect of gender on EI and its antecedents were missing in previous literature. Therefore, these findings give quantitative proof to findings of previous conceptual and qualitative papers $[35,59]$.

Because of this, the predictors masculinity and femininity are very interesting independent variables to integrate into study models since other researchers stated that sex is not a sufficient predictor of entrepreneurial intentions [84, 96, 97].

\subsection{Implications Related to the Context of Entrepreneurship, Gender and Intersectionality}

Masculinity (strong personality, forcefulness, leadership,...) have an impact on EI, ATB and SN. This means that people with low masculinity should get empowered in another way than people with high masculinity. According to [98], exposure to role models can positively affect entrepreneurial intentions since it generates role model identification and favorable attitudes towards entrepreneurship, in which there is a quest for entrepreneurship education via storytelling. With these kinds of stories, the lack of fit between low masculine stereotypes and entrepreneurship [64, 71] could possibly be unblocked, and hence the obstacles towards the entrepreneurial intentions of low masculine oriented persons could be diminished. Other researchers have also proven the importance of role models and success stories of entrepreneurs as an important factor for influencing entrepreneurial intention in a positive way [99-101].

Beyond all expectations, students with high femininity are more easily influenced by the judgement of other important people (family, friends, etc.) than students with low femininity $(\mathrm{H} 3 \mathrm{c})$. This can be explained by linking the factors of femininity to subjective norms. Some factors of femininity are sensitivity to the needs of others, and being understanding, affectionate and compassionate [22]. These factors imply emotional characteristics, which show that the needs of others play an important role in these people's lives. Role models and the success stories of people who are important in the eyes of young entrepreneurs can influence the subjective norm of the respondents and eventually their intentions.
Finally, the additional insights show that masculinity is also a strong predictor for both male and female students separately. Masculine male students have significantly more EI than non-masculine male students, and masculine female students have significantly more EI than non-masculine female students. This implies that a huge new research stream could evolve: although male and female entrepreneurs are stereotyped, there are also intersectional differences. This study reveals there is no typical male entrepreneur or female entrepreneur, but there should be more attention for intersectionality of entrepreneurs with high or low masculinity and high or low femininity. Disadvantages based on intersecting social positions of gender were already studied [102], but this article also explains why sometimes female students with high masculine or feminine traits find more easily support of their family and friends via their subjective norms, what could bring less difficulties in a later stadium in accessing formal or informal social and financial support [103]. Therefore research on male and female entrepreneurship with an emphasis on intersectionality becomes more and more important, which is still scanty [104].

\subsection{Contributions, Limitations and Further Research}

In light of the proposed research gap, this paper aimed to investigate whether entrepreneurial intention and its antecedents are affected by sex, masculinity and/or femininity. Giving an answer to the research question of this article, we can state that a higher score of entrepreneurial intention depends on the fact whether a person is male, but also if a person has high scores for masculinity: high masculine male students have more EI than low masculine male students, and furthermore high masculine female students have more EI than low masculine female students. Finally high femininity is a good predictor for EI with SN as mediator.

This study contributes to the existing literature by integrating masculinity and femininity as predictors for entrepreneurial intention in general. Former studies did in fact find differences between men and women [47, 49, 105], while others did not find any significant discrepancy [97, 106]. Because former research found biased conclusions regarding the relation between sex and entrepreneurial intention, this study offers hints why this could be the case, suggesting a new approach as a result: masculinity and femininity are very interesting independent variables to integrate into study models.

Since this study was conducted in the area of business management, this paper contributes to the current understanding how educators could address students with high and with low masculinity and/or femininity. Since students with high masculinity already have high intentions, educators could start to think how they can influence students with low masculinity to become more entrepreneurially minded.

The survey of this paper is limited by its approach and sample. Although this research was performed on a relatively large cohort of senior undergraduate students in business management at two large universities in Belgium, some of its conclusions cannot be generalized for all (Flemish) students of business management. Future research could compare 
students from different countries, offering intersectional differences between students from various European countries to control for the impact of different cultural background on EI in general, and specifically regarding the cultural enablers and obstacles when it comes to the dissonance of gender stereotypes and entrepreneurship.

Second, since only students are surveyed, conclusions aimed at non-students are questionable. Performing surveys on people who are already in the workforce could achieve different outcomes. Upcoming research could have its emphasis on people who are or are not self-employed to see what the differences are, all while using a quantitative and qualitative survey of how masculinity and femininity influence entrepreneurial intentions.

Surveying entrepreneurial intention from a socially constructed gender awareness perspective offers a different approach and gives new insights into what is important for fostering entrepreneurship. To sum up, this paper opens a discussion on the terminology and variables used in the past to differentiate and discuss entrepreneurial intention. Although there are less women entrepreneurs compared to men, still there are also many men who are not showing entrepreneurial intention as well. Further research about entrepreneurial intention and women entrepreneurship should not (only) focus on sex, but definitely also on gender characteristics like masculinity and femininity.

\section{References}

[1] United, N. Speakers Stress Key Role of Entrepreneurship in Sustainable Development, as Second Committee Approves 3 Draft Resolutions. 2016 10/09/2018]; Available from: https://www.un.org/press/en/2016/gaef3465.doc.htm.

[2] European, C., (2013). Entrepreneurship 2020 Action Plan: Reigniting the Entrepreneurial Spirit in Europe. 1-18.

[3] Huggins, R. and P. Thompson, (2015). Entrepreneurship, innovation and regional growth: a network theory. Small Business Economics, 45 (1): 103-128.

[4] Cavusgil, S. T. and G. Knight, (2015). The born global firm: An entrepreneurial and capabilities perspective on early and rapid internationalization. Journal of International Business Studies, 46 (1): 3-16.

[5] De Bruin, A., C. G. Brush and F. Welter, (2006). Introduction to the special issue: Towards building cumulative knowledge on women's entrepreneurship. Entrepreneurship Theory and practice, 30 (5): 585-593.

[6] De Bruin, A., C. G. Brush and F. Welter, (2007). Advancing a framework for coherent research on women's entrepreneurship. Entrepreneurship theory and practice, 31 (3): 323-339.

[7] Henry, C., L. Foss and H. Ahl, (2016). Gender and entrepreneurship research: A review of methodological approaches. International Small Business Journal, 34 (3): 217-241.

[8] Greene, P., C. Brush and E. Gatewood, (2006). Perspectives on women entrepreneurs past findings and new directions. Entrepreneurship: The Engine of Growth, 1: 181-204.
[9] Ahl, H., (2006). Why Research on Women Entrepreneurs Needs New Directions. Entrepreneurship theory and practice, 30 (5): 595-621.

[10] Shinnar, R. S., O. Giacomin and F. Janssen, (2012). Entrepreneurial Perceptions and Intentions: The Role of Gender and Culture. Entrepreneurship: Theory \& Practice, 36 (3): 465-493.

[11] Tegtmeier, S. and J. Mitra, (2015). Gender perspectives on university education and entrepreneurship. International Journal of Gender and Entrepreneurship, 7 (3): 254-271.

[12] Mehtap, S., M. M. Pellegrini, A. Caputo and D. H. Welsh, (2017). Entrepreneurial intentions of young women in the Arab world: Socio-cultural and educational barriers. International Journal of Entrepreneurial Behavior \& Research, 23 (6): $880-902$.

[13] Tedmanson, D., K. Verduyn, C. Essers and W. B. Gartner, Critical perspectives in entrepreneurship research. 2012, Sage Publications Sage UK: London, England.

[14] Brush, C. G., A. De Bruin and F. Welter, (2009). A gender-aware framework for women's entrepreneurship. International Journal of Gender and Entrepreneurship, 1 (1): $8-24$.

[15] Brush, C. G., A. de Bruin and F. Welter, (2014). Advancing theory development in venture creation: signposts for understanding gender. Women's entrepreneurship in the 21 st century: an international multi-level research analysis, 11.

[16] Brush, C. G., L. F. Edelman, T. Manolova and F. Welter, (2018). A gendered look at entrepreneurship ecosystems. Small Business Economics: 1-16.

[17] Welter, F., C. G. Brush and A. De Bruin, (2014). The gendering of entrepreneurship context.

[18] García, M.-C. D. and F. Welter, (2013). Gender identities and practices: Interpreting women entrepreneurs' narratives. International Small Business Journal, 31 (4): 384-404.

[19] Marlow, S. and A. Martinez Dy, (2017). Annual review article: Is it time to rethink the gender agenda in entrepreneurship research? International Small Business Journal: 0266242617738321 .

[20] Birkner, S., K. Ettl, F. Welter and I. Ebbers, Women's Entrepreneurship in Europe: Research Facets and Educational Foci, in Women's Entrepreneurship in Europe, S. Birkner, et al., Editors. 2018, Springer: Heidelberg. p. 3-13.

[21] Ajzen, I., From intentions to actions: A theory of planned behavior, in Action control, K. Jürgen and B. Julius, Editors. 1985, Springer: Heidelberg, Germany. p. 11-39.

[22] Bem, S. L., (1981). Gender schema theory: A cognitive account of sex typing. Psychological review, 88 (4): 354.

[23] Brush, C. G., Women entrepreneurs: A research overview, in The Oxford handbook of entrepreneurship. 2006.

[24] Birley, S., (1987). Female entrepreneurs: are they really any different?

[25] Watkins, J. M. and D. S. Watkins, (1983). The female entrepreneur: her background and determinants of business choice-some British data. Frontiers of entrepreneurship research: 271-288. 
[26] Chaganti, R., (1986). Management in women-owned enterprises. Journal of small business management, 24: 18.

[27] Berry, M. C., (1980). Targeting more aid to women entrepreneurs. Venture May: 294-304.

[28] Marlow, S., (1997). Self-employed women-new opportunities, old challenges? Entrepreneurship \& Regional Development, 9 (3): 199-210.

[29] Mirchandani, K., (1999). Feminist insight on gendered work: New directions in research on women and entrepreneurship. Gender, Work \& Organization, 6 (4): 224-235.

[30] Hughes, K. D., J. E. Jennings, C. Brush, S. Carter and F. Welter, (2012). Extending Women's Entrepreneurship Research in New Directions. Entrepreneurship Theory and Practice, 36 (3): 429-442.

[31] Rouse, J., L. Treanor and E. Fleck, (2013). The gendering of entrepreneurship: theoretical and empirical insights. International Journal of Entrepreneurial Behaviour \& Research, 19 (5): 452-459.

[32] Baughn, C. C., B. L. Chua and K. E. Neupert, (2006). The normative context for women's participation in entrepreneruship: A multicountry study. Entrepreneurship Theory and Practice, 30 (5): 687-708.

[33] Manolova, T. S., N. M. Carter, I. M. Manev and B. S. Gyoshev, (2007). The differential effect of men and women entrepreneurs' human capital and networking on growth expectancies in Bulgaria. Entrepreneurship Theory and Practice, 31 (3): 407-426.

[34] Wilson, F., J. Kickul and D. Marlino, (2007). Gender, Entrepreneurial Self-Efficacy, and Entrepreneurial Career Intentions: Implications for Entrepreneurship Education. Entrepreneurship: Theory \& Practice, 31 (3): 387-406.

[35] Hamilton, E., (2013). The discourse of entrepreneurial masculinities (and femininities). Entrepreneurship \& Regional Development, 25 (1-2): 90-99.

[36] Jennings, J. E. and C. G. Brush, (2013). Research on women entrepreneurs: challenges to (and from) the broader entrepreneurship literature? Academy of Management Annals, 7 (1): 663-715.

[37] Bruni, A., S. Gherardi and B. Poggio, (2004). Entrepreneur-mentality, gender and the study of women entrepreneurs. Journal of Organizational Change Management, 17 (3): 256-268.

[38] Krueger, N. F., M. D. Reilly and A. L. Carsrud, (2000). Competing models of entrepreneurial intentions. Journal of business venturing, 15 (5): 411-432.

[39] Kautonen, T., M. Gelderen and M. Fink, (2015). Robustness of the theory of planned behavior in predicting entrepreneurial intentions and actions. Entrepreneurship Theory and Practice, 39 (3): 655-674.

[40] Bird, B., (1988). Implementing entrepreneurial ideas: The case for intention. Academy of management Review, 13 (3): 442-453.

[41] Armitage, C. J. and M. Conner, (2001). Efficacy of the theory of planned behaviour: A meta-analytic review. British journal of social psychology, 40 (4): 471-499.

[42] Sheeran, P., (2002). Intention-behavior relations: A conceptual and empirical review. European review of social psychology, 12 (1): 1-36.

[43] Drnovsek, M. and T. Erikson, (2005). Competing models of entrepreneurial intentions. Economic and Business Review for Central and South-Eastern Europe, 7 (1): 55.

[44] Haus, I., H. Steinmetz, R. Isidor and R. Kabst, (2013). Gender effects on entrepreneurial intention: A meta-analytical structural equation model. International Journal of Gender and Entrepreneurship, 5 (2): 130-156.

[45] Schwarz, E. J., M. A. Wdowiak, D. A. Almer-Jarz and R. J. Breitenecker, (2009). The effects of attitudes and perceived environment conditions on students' entrepreneurial intent. Education \& Training, 51 (4): 272-291.

[46] Joensuu, S., A. Viljamaa, E. Varamäki and E. Tornikoski, (2013). Development of entrepreneurial intention in higher education and the effect of gender - a latent growth curve analysis. Education \& Training, 55 (8/9): 781-803.

[47] Kurczewska, A. and J. Bialek, (2014). Is the interplay between self-efficacy and entrepreneurial intentions gender-dependent? Argumenta Oeconomica, 33 (2): 23-38.

[48] Kourilsky, M. L. and W. B. Walstad, (1998). Entrepreneurship and female youth: Knowledge, attitudes, gender differences, and educational practices. Journal of Business venturing, 13 (1): 77-88.

[49] Vukovic, K., I. Kedmenec and D. Korent, (2015). The Impact of Exposure to Entrepreneurship Education on Student Entrepreneurial Intentions. Croatian Journal of Education-Hrvatski Casopis Za Odgoj I Obrazovanje, 17 (4): 1009-1036.

[50] Camelo-Ordaz, C., J. P. Diánez-González and J. Ruiz-Navarro, (2016). The influence of gender on entrepreneurial intention: The mediating role of perceptual factors. BRQ Business Research Quarterly, 19 (4): 261-277.

[51] Shinnar, R. S., D. K. Hsu, B. C. Powell and H. Zhou, (2018). Entrepreneurial intentions and start-ups: Are women or men more likely to enact their intentions? International small business journal, 36 (1): 60-80.

[52] Itani, H., Y. M. Sidani and I. Baalbaki, (2011). United Arab Emirates female entrepreneurs: motivations and frustrations. Equality, Diversity and Inclusion: An International Journal, 30 (5): 409-424.

[53] Morris, M. H. and P. S. Lewis, (1995). The determinants of entrepreneurial activity: Implications for marketing. European journal of marketing, 29 (7): 31-48.

[54] Brindley, C., (2005). Barriers to women achieving their entrepreneurial potential: Women and risk. International Journal of Entrepreneurial Behavior \& Research, 11 (2): 144-161.

[55] Heilman, M. E., (2001). Description and prescription: How gender stereotypes prevent women's ascent up the organizational ladder. Journal of social issues, 57 (4): 657-674.

[56] Lansky, M., (2000). Gender, women and all the rest (Part 1). International Labour Review, 139 (4): 481.

[57] Marlow, S. and M. McAdam, (2013). Gender and entrepreneurship: Advancing debate and challenging myths; exploring the mystery of the under-performing female entrepreneur. International Journal of Entrepreneurial Behavior \& Research, 19 (1): 114-124. 
[58] Brush, C. G., N. M. Carter, E. J. Gatewood, P. G. Greene and M. M. Hart, Women and entrepreneurship. 2006: Edward Elgar Publishing.

[59] Jones, S., (2014). Gendered discourses of entrepreneurship in UK higher education: The fictive entrepreneur and the fictive student. International Small Business Journal, 32 (3): 237-258.

[60] Nwankwo, B. E., G. C. Kanu, M. I. Marire, S. K. Balogun and A. C. Uhiara, (2012). Gender-role orientation and self-efficacy as correlates of entrepreneurial intention. European Journal of Business and Social Sciences, 1 (6): 9-26.

[61] Carter, N. M. and M. L. Williams, (2003). The case of new firm growth. New perspectives on women entrepreneurs, 3: 25.

[62] Oakley, A., Sex, gender and society. 2016: Routledge.

[63] Vafaei, A., B. Alvarado, C. Tomás, C. Muro, B. Martinez and M. V. Zunzunegui, (2014). The validity of the 12-item Bem Sex Role Inventory in older Spanish population: An examination of the androgyny model. Archives of gerontology and geriatrics, 59 (2): 257-263.

[64] Gupta, V. K., D. B. Turban, S. A. Wasti and A. Sikdar, (2009). The role of gender stereotypes in perceptions of entrepreneurs and intentions to become an entrepreneur. Entrepreneurship theory and practice, 33 (2): 397-417.

[65] Matsui, T. and M. L. Onglatco, (1991). Instrumentality, expressiveness, and self-efficacy in career activities among Japanese working women. Journal of Vocational Behavior, 39 (2): $241-250$

[66] Perez-Quintana, A., E. Hormiga, J. C. Martori and R. Madariaga, (2017). The influence of sex and gender-role orientation in the decision to become an entrepreneur. International Journal of Gender and Entrepreneurship, 9 (1): 8-30.

[67] Sweida, G., The Woman Entrepreneur's Paradox: Entrepreneurial Intention, Entrepreneurial Self-efficacy, and Behavior. 2018, The Claremont Graduate University.

[68] Díaz-García, M. C. and J. Jiménez-Moreno, (2010). Entrepreneurial intention: the role of gender. International Entrepreneurship and Management Journal, 6 (3): 261-283.

[69] Ahl, H. and T. Nelson, (2015). How policy positions women entrepreneurs: A comparative analysis of state discourse in Sweden and the United States. Journal of Business Venturing, 30 (2): 273-291.

[70] Brooks, A. W., L. Huang, S. W. Kearney and F. E. Murray, (2014). Investors prefer entrepreneurial ventures pitched by attractive men. Proceedings of the National Academy of Sciences, 111 (12): 4427-4431.

[71] Lee, M. and L. Huang, (2018). Gender bias, social impact framing, and evaluation of entrepreneurial ventures. Organization Science, 29 (1): 1-16.

[72] Sánchez, J. C. and O. Licciardello, (2012). Gender differences and attitudes in entrepreneurial intentions: the role of career choice. JWEE, (1-2): 7-27.

[73] Smallbone, D. and F. Welter, (2006). Conceptualising entrepreneurship in a transition context. International Journal of Entrepreneurship and Small Business, 3 (2): 190-206.

[74] Manigart, S., B. Clarysse, H. Crijns and H. Goossens, (2002).
The Global Entrepreneurship Monitor: Executive Report Belgium and Flanders 2001.

[75] Holvoet, T., N. Bosma and H. Crijns, (2015). Global Entrepreneurship Monitor 2014. Samenvatting voor Vlaanderen.

[76] Liñán, F. and Y. W. Chen, (2009). Development and Cross-Cultural application of a specific instrument to measure entrepreneurial intentions. Entrepreneurship theory and practice, 33 (3): 593-617.

[77] Kolvereid, L., (2016). Preference for self-employment: Prediction of new business start-up intentions and efforts. The International Journal of Entrepreneurship and Innovation, 17 (2): 100-109.

[78] Fayolle, A., B. Gailly and N. Lassas-Clerc, (2006). Assessing the impact of entrepreneurship education programmes: a new methodology. Journal of European industrial training, 30 (9): 701-720.

[79] Kolvereid, L., (1996). Prediction of employment status choice intentions. Entrepreneurship: Theory and Practice, 21 (1): 47-58.

[80] Souitaris, V., S. Zerbinati and A. Al-Laham, (2007). Do entrepreneurship programmes raise entrepreneurial intention of science and engineering students? The effect of learning, inspiration and resources. Journal of Business venturing, 22 (4): 566-591.

[81] Varamäki, E., S. Joensuu, E. Tornikoski and A. Viljamaa, (2015). The development of entrepreneurial potential among higher education students. Journal of Small Business and Enterprise Development, 22 (3): 563-589.

[82] Campbell, T., J. A. Gillaspy Jr and B. Thompson, (1997). The factor structure of the Bem Sex-Role Inventory (BSRI): Confirmatory analysis of long and short forms. Educational and Psychological Measurement, 57 (1): 118-124.

[83] Maresch, D., R. Harms, N. Kailer and B. Wimmer-Wurm, (2016). The impact of entrepreneurship education on the entrepreneurial intention of students in science and engineering versus business studies university programs. Technological Forecasting and Social Change, 104: 172-179.

[84] Tiago, T., S. Faria, J. P. Couto and F. Tiago, (2015). Fostering Innovation by Promoting Entrepreneurship: From Education to Intention. Procedia - Social and Behavioral Sciences, 175: 154-161.

[85] Seaman, C., R. Bent and A. Unis, (2016). Family entrepreneurship culture, entrepreneurial intent, futures and foresight in Scottish Pakistani communities. Futures, 75: $83-91$

[86] Lindquist, M. J., J. Sol and M. Van Praag, (2015). Why do entrepreneurial parents have entrepreneurial children? Journal of Labor Economics, 33 (2): 269-296.

[87] Fayolle, A. and B. Gailly, (2015). The impact of entrepreneurship education on entrepreneurial attitudes and intention: Hysteresis and persistence. Journal of Small Business Management, 53 (1): 75-93.

[88] Donnelly, K. and J. M. Twenge, (2017). Masculine and feminine traits on the Bem Sex-Role Inventory, 1993-2012: A cross-temporal meta-analysis. Sex Roles, 76 (9): 556-565. 
[89] Allison, P., (2012). When can you safely ignore multicollinearity. Statistical Horizons, 5 (1).

[90] Hoaglin, D. C. and B. Iglewicz, (1987). Fine-tuning some resistant rules for outlier labeling. Journal of the American statistical Association, 82 (400): 1147-1149.

[91] Ng, M. and J. Lin, (2016). Testing for mediation effects under non-normality and heteroscedasticity: a comparison of classic and modern methods. International Journal of Quantitative Research in Education, 3 (1-2): 24-40.

[92] Banjanovic, E. S. and J. W. Osborne, (2016). Confidence intervals for effect sizes: Applying bootstrap resampling. Practical Assessment, Research, and Evaluation, 21 (1): 5.

[93] Sobel, M. E., (1982). Asymptotic confidence intervals for indirect effects in structural equation models. Sociological methodology, 13: 290-312.

[94] Preacher, K. J. and A. F. Hayes, (2004). SPSS and SAS procedures for estimating indirect effects in simple mediation models. Behavior research methods, instruments, \& computers, 36 (4): 717-731.

[95] Lenney, E., (1991). Sex roles: The measurement of masculinity, femininity, and androgyny.

[96] Hytti, U., P. Stenholm, J. Heinonen and J. Seikkula-Leino, (2010). Perceived learning outcomes in entrepreneurship education. Education \& Training, 52 (8/9): 587-606.

[97] Dabic, M., T. Daim, E. Bayraktaroglu, I. Novak and M. Basic, (2012). Exploring gender differences in attitudes of university students towards entrepreneurship. International Journal of Gender and Entrepreneurship, 4 (3): 316-336.

[98] Laviolette, E. M., M. R. Lefebvre and O. Brunel, (2012). The impact of story bound entrepreneurial role models on self-efficacy and entrepreneurial intention. International Journal of Entrepreneurial Behavior \& Research.
[99] Boissin, J.-P., B. Branchet, S. Delanoë and V. Velo, (2011). Gender's Perspective of Role Model Influence on Entrepreneurial Behavioral Beliefs. International Journal of Business, 16 (2): 182-206.

[100] Kailer, N., (2009). Entrepreneurship education: empirical findings and proposals for the design of entrepreneurship education concepts at universities in German-speaking countries. Journal of Enterprising Culture, 17 (2): 201-231.

[101] Shneor, R. and J. I. Jenssen. A comparison of factors influencing male and female students' entrepreneurial intentions. in 5th Annual Euromed Conference of the Euromed Academy of Business: Building New Business Models for Success through Competitiveness and Responsibility. 2014.

[102] Dy, A. M., S. Marlow and L. Martin, (2017). A Web of opportunity or the same old story? Women digital entrepreneurs and intersectionality theory. Human Relations, 70 (3): 286-311.

[103] Fielden, S. and M. J. Davidson, (2012). BAME women business owners: how intersectionality affects discrimination and social support. Gender in management: An international journal.

[104] Romero, M. and Z. Valdez, (2016). Introduction to the special issue: Intersectionality and entrepreneurship. Ethnic and Racial Studies, 39 (9): 1553-1565.

[105] Yordanova, D. I. and M.-A. Tarrazon, (2010). Gender differences in entrepreneurial intentions: evidence from Bulgaria. Journal of Developmental Entrepreneurship, 15 (3): 245-261.

[106] Küttim, M., M. Kallaste, U. Venesaar and A. Kiis, (2014). Entrepreneurship education at university level and students' entrepreneurial intentions. Procedia - Social and Behavioral Sciences, 110: 658-668. 